\title{
The literacy and numeracy 'crisis' in Australian workplaces: discursive rhetoric versus production floor realities
}

\author{
Stephen Black, Keiko Yasukawa and Tony Brown, \\ University of Technology Sydney
}

\begin{abstract}
The dominant discourse on adult literacy and numeracy in Australia sees the federal government, industry, workforce skills agencies and the media speaking with one voice on the 'crisis' involving workers' low literacy and numeracy skills. Underpinning this discourse are the Australian results of the international Adult Literacy and Life Skills Survey (ALLS) which are used to model correlations between low literacy/numeracy levels and productivity. In turn, these correlations are deemed to have implications for the competitiveness of individual enterprises and the prosperity of the nation. In the ALLS, approximately half of manufacturing workers are found at the lowest two levels. Adopting an ethnographic perspective, and viewing literacy and numeracy as social practices, this paper investigates this 'crisis' from the situated perspectives of managers, trainers and workers in three manufacturing companies. Multiple observations of production work and semi-structured interviews with over 50 company personnel reveal a contradiction between the crisis discourse rhetoric on workplace literacy and numeracy and the realities of production work. Literacy and numeracy are found not to have a negative influence on production work in the three companies. This raises questions about the basis for the crisis discourse, and government policy and programmes that flow from it.
\end{abstract}

Key words: workplace, literacy, numeracy, social practices, lean production

\section{Introduction}

This paper focuses on English literacy (including spoken English) and numeracy in Australian workplace contexts, and in particular, the discourse of a literacy and numeracy 'crisis' promoted strongly by governments, industry/skills groups and the media. We outline how this dominant crisis discourse links the low literacy and numeracy levels of workers, as determined by large scale surveys and also surveys of employer perspectives, with low productivity in workplaces. Largely in response to this discourse, government policy and funding in the area of adult literacy and numeracy are skewed heavily towards a human capital rationale articulated mainly in the form of funding for workplace and jobseeker programmes. However, the discursive rhetoric associated with this crisis is challenged in this paper by a study drawing on research from another methodological approach, an ethnographic perspective, which analyses workers' literacy and numeracy practices in three manufacturing companies in the process of transitioning to lean production processes. 
There are very few in-depth, 'situated' studies of literacy and numeracy in Australian workplace contexts, despite the need, expressed more than a decade ago by leading Australian literacy theorists such as Freebody $(1997,14)$, for 'principled ethnographic' studies that provide alternative perspectives to the way literacy is 'prescribed' (15) by powerful institutions. This is the research gap this study targets, providing ethnographic data at the manufacturing company level which calls into question and counters the dominant 'crisis' perspectives of government, industry and skills agencies. The focus on 'lean' manufacturing (discussed later in the paper) is significant because it is seen by industry to represent 'more sophisticated skills' (e.g. Australian Industry Group 2012, 84), and thus is likely to highlight literacy and numeracy issues and problems, especially in view of the lower literacy/numeracy skills of the manufacturing workforce as identified in the ALLS survey.

The aims of this study were: firstly, to identify the range of workplace practices with embedded literacy and numeracy in production work in the three manufacturing companies; and secondly, to document the perspectives of workers, trainers and managers in relation to how workers manage these practices. As indicated, the approach was ethnographic, providing the situated perspectives of these company personnel. As we will see, the production floor realities, as expressed in recorded interviews and through observations of workplace practices, largely contradict the crisis discourse. This has implications for how the discourse itself is constituted, and the government policy and programmes that result from it.

\section{The literacy and numeracy 'crisis' in Australian workplaces}

The National Foundation Skills Strategy for Adults (hereafter, the Strategy) was launched in September 2012 (Standing Council on Tertiary Education, Skills \& Employment 2012). It represents the official state of play in Australian adult literacy and numeracy policy and practice currently and for at least the next decade. It is the first major government policy document on adult literacy and numeracy since the Australian Language and Literacy Policy more than two decades ago (Department of Employment, Education and Training 1991). It should be noted firstly that the term 'foundation skills' is used in the Strategy in preference to literacy and numeracy. Foundation skills are defined as the combination of English language, literacy and numeracy and:

employability skills such as collaboration, problem solving, selfmanagement, learning and information and communication technology (ICT) skills required for participation in modern workplaces and contemporary life (Standing Council on Tertiary Education, Skills \& Employment 2012, 2).

Thus conceptually with use of the umbrella term 'foundation skills', literacy and numeracy skills are now officially joined with employment related skills. The Strategy can be seen to have a predominantly human capital focus, and one of its key priority areas is 'strengthening foundation skills in the workplace' (3), which is seen to provide support to employers and to underpin the nation's economic prosperity (4-7). The 
Strategy reinforces the Australian government's budget priorities in recent years of substantially increasing funding for workplace and jobseeker literacy and numeracy programmes (Australian Government 2010). Throughout the Strategy extensive references are made to recent reports of industry and workforce development agencies which have lobbied hard in recent years for government funding for developing workplace literacy and numeracy skills. The peak industry organisation, the Australian Industry Group, in particular has received substantial government funding to undertake its own studies of workplace literacy and numeracy, leading to its often-quoted survey finding that $75 \%$ of employers reported their business was affected by low levels of literacy and numeracy (Australian Industry Group 2010, 2012). The then Chief Executive Officer of the Australian Industry Group writing in The Australian newspaper 26 May 2010 argued:

Its implications for business are enormous: safety risks are increased when signs and safety information can't be read; productivity is reduced and waste is increased when standard operating procedures and other work instructions can't be fully understood ...

The 'literacy crisis' can be seen as a key element of the more general 'skills crisis' in Australia. Organisations such as Skills Australia (recently re-named Australian Workforce and Productivity Agency), have originated in recent years specifically to address existing and likely future workforce development and training needs seen to underpin productivity and national prosperity (e.g. Skills Australia 2011, Australian Workforce and productivity Agency 2013). In the various reports of Skills Australia literacy and numeracy feature prominently and are considered 'fundamental to workforce productivity' (2010, 35-37), and reference is made to 'the imperative' to lift foundation skills $(2011,113-116)$ in the interests of the nation's prosperity. In a similar vein, the Industry Skills Councils (2011) claim there is a national urgency to address workplace literacy and numeracy issues with a report entitled No more excuses.

Apart from employer surveys, the primary source of data and legitimacy for these claims of low literacy and numeracy skills among Australian workers is the Adult Literacy and Life Skills Survey, (ALLS, see Australian Bureau of Statistics 2007) which forms part of the International Adult Literacy Survey managed by Statistics Canada and the OECD. The Australian survey undertaken in 2006 shows levels of literacy according to four domains - prose literacy, document literacy, numeracy, and problem solving and within each domain there are five skill levels (only four in problem solving). Based on a citation from a Statistics Canada/OECD publication, the survey identifies level three as the minimum required for individuals to meet the complex demands of everyday life and work in the emerging knowledge-based economy (Australian Bureau of Statistics 2007, 5). It is the extrapolation of this level three criterion that enables governments, industry and various other agencies, including the media, to make claims about the extent of low literacy and numeracy among Australian adults. This criterion forms the basis for example, of a national radio comment by the former Chief Executive Officer of the Australian Industry Group that 'there are seven million people in the Australian workforce that just can't do it. They can't read standard operating procedures, for example ...' (Australian Broadcasting Corporation 2010). A similar 
figure is cited by the Federal Minister Senator Chris Evans in the opening words of his Foreword to the Strategy: 'More than 7.5 million Australian adults do not have the literacy and numeracy skills to participate fully in today's workforce' (Standing Council on Tertiary Education, Skills \& Employment 2012, i). ALLS data are also used in statistical modelling to claim that improvements in the nation's ALLS literacy levels will result in improved labour force participation and hourly wage rates (Shomos 2010), and these claims have been referenced many times in government and business reports, including in the recent Strategy.

To date, the ALLS data have been accepted by the full range of stakeholders, including governments, industry and workforce development agencies, the media and leading educational testing agencies, who, according to Robin Shreeve, Chief Executive Officer of Skills Australia, are largely 'singing off the same hymn sheet' (Canberra Institute of Technology 2010). The Strategy effectively represents this single voice in its promotion of workplace programmes to redress literacy and numeracy problems with claims that these programmes enhance efficiency and productivity, improve flexibility in adapting to technological changes, retain staff, increase compliance with occupational health and safety standards, and improve self confidence and team work (Standing Council on Tertiary Education, Skills \& Employment 2012, 7). Integral to all these programmes is the need to assess workers/learners using a national standardised measure, the Australian Core Skills Framework, (the ACSF ${ }^{1}$ ).

The discourse therefore is one of deficit - that large numbers of Australian workers have been formally assessed (either through the ALLS or the ACSF) as not meeting benchmarks in literacy and numeracy, and therefore they need to undertake workplace training to remedy the situation. This discourse has been repeated so many times in national forums that it has become 'common sense', representing a naturalised discourse (e.g. Fairclough 1989). It has been encapsulated recently by Fenwick (2010, 319), writing from a Canadian perspective, as one which:

... continues to emphasise skill acquisition in a conventional deficitoriented, individualist and universalist model of work education, where the educational goals are upskilling through control and measurement.

\section{Alternative perspectives}

Literacy crises have long been recognised as 'political'. Critical educator Michael Apple (1987: viii), for example, once commented: 'Whenever dominant groups declare that there is a crisis, we must always ask 'Whose crisis is this?' and 'Who benefits from the proposed 'solutions'. Apple (1987), along with other critical educators responding to literacy crises in different eras, has suggested that there are advantages to dominant groups in effectively attempting, through the crisis discourse, to shift macro socioeconomic problems such as skill shortages, onto the failings of individuals to acquire, or school systems to provide, the right level of literacy and numeracy skills (see Aronowitz and Giroux 1985, Shor 1986, Freebody and Welch 1993). Further, at a more pragmatic

\footnotetext{
${ }^{1}$ http://www.innovation.gov.au/Skills/LiteracyAndNumeracy/AustralianCoreSkillsFramework/Pages/default.aspx
} 
level, literacy crisis discourses may bring benefits to powerful industry organisations because they result in priority government investments in skills in their sector (Black and Yasukawa 2011). Recent national budget increases for government subsidised workplace literacy programmes are a demonstration of this benefit (Australian Government 2010).

Some specific studies of workplace literacy and numeracy also present alternative discourses to the current Australian crisis discourse outlined previously. Hoddinott (1997), for example, in a doctoral study of workplace literacy programmes in the United States, Canada and the UK highlighted their ideological nature, and concluded that the basic skills 'crisis' was socially constructed and had little or no basis of fact (see also Holland, Frank and Cooke 1998). Several UK reports, have reviewed the literature and undertaken longitudinal studies to conclude that there is little evidence that workplace literacy/numeracy programmes result in improved wages, employment outcomes or productivity increase, at least not in the short term (see Ananiadou et al. 2004; Meadows and Metcalf 2008). As part of the Skills for Life initiative Wolf et al. (2010) in a longitudinal study of 53 UK government-subsidised workplace basic skills programmes, found no changed behaviours likely to affect productivity, and the programmes amounted to a costly approach with no lasting legacy for the employer (see also Wolf and Evans 2011).

A growing number of studies in the past two decades have examined workplace literacy and numeracy issues from the local perspectives of the workers themselves, and how these issues play out within the social dynamics and hierarchies of workplaces. These research studies are predominantly ethnographic, and they reveal a far more complex and nuanced picture of literacy and numeracy in workplaces. Gowen (1992, 1996), for example, in early studies of hospital and manufacturing workers, demonstrates the 'politics' of workplace literacy, and the way management can use literacy issues to privilege their own more powerful positions. Other North American studies (Hull 1993, 1997; Hart-Landsberg and Reder 1995; Gee, Hull and Lankshear 1996; Darrah 1996; Tannock 1997; Jackson 2000; Belfiore et al. 2004; Hull, Jury and Zacher 2007; Jackson and Slade 2008; and Gallo 2008), and limited Australian (e.g. Black 2004; Farrell 2006; Scheeres 2007; Black and Yasukawa 2011) and New Zealand studies (Kell et al. 2009; Hunter 2012; Hastwell, Strauss and Kell 2013), similarly indicate that literacy and numeracy 'problems' which employers identify in their workplaces are rarely straightforward. In fact, in a technical sense they are often not found to be 'problems' at all. As Hull, Jury and Zacher (2007, 304) in their study of Silicon Valley production workers commented:

In four years of documenting work at two large companies, we simply did not find literacy problems of the sort that once were popularised by the press as accounting for US failure to compete economically.

Rather, the key 'problems' arising in workplaces and affecting productivity levels can often be seen to occur mainly in the context of relations of power as attempts are made 
to change the way workers work, not just in terms of their skills, but their identities, attitudes and motivations. Gowen $(1996,26)$ encapsulates this point in her study of a manufacturing company in the United States in which she writes of the need to better understand 'the deeply embedded power relations that drive productivity and commitment much more than literacy skills ever will'. Williams and Wake (2007) in a UK study of mathematical practices in manufacturing companies, demonstrated how power could relate to knowledge embedded in 'black boxes'. Workers are trained only to operate equipment while denied access to the underlying knowledge about the formula or algorithm that makes the equipment work. Some supervisory personnel saw the protection of this knowledge from the staff they supervised as a way of maintaining their authority and power in the workplace.

Understanding the role and significance of literacy and numeracy in workplaces requires the additional perspectives of the workers themselves; what they are experiencing and learning (Foley 1999; Black 2004; Rose 2004; Livingstone and Sawchuk 2005), or as Hull (1993) describes it, 'hearing other voices'. Many of the above studies of worker perceptions view literacy and numeracy primarily as social practices, building on the body of literature known as the 'New Literacy Studies' (e.g. Gee 1990; Baynham 1995; Street 1995; Barton and Hamilton 1998; Barton 2007). In contrast to a uni-dimensional and 'autonomous' literacy and numeracy, that is, literacy and numeracy as well-defined, context independent skills ('this literacy thing' as one industry Chief Executive Officer calls it - see Australian Broadcasting Corporation 2010), these researchers focus on the many and varied literacy and numeracy practices (or literacies and numeracies) which people engage in and value in their everyday lives. In this study our concern is with literacy and numeracy 'embedded' in workplace practices (see Derrick 2012), that is, where language, texts and mathematics are constitutive elements of work practices. The social practices view acknowledges that literacy and numeracy embedded in workplace practices are contingent on the contexts of particular work tasks that are in turn influenced by the culture and politics of the workplace. Examining these practices can best be achieved through the in-depth 'thick' descriptions provided by ethnographic research approaches.

Research in mathematics in the workplace also points to the importance of an ethnographic approach to researching peoples' work rather than to search out mathematics which 'preserves the hegemony of particular forms of knowing and doing' (Zevenbergen and Zevenbergen 2009, 184; Skovsmose and Yasukawa 2009). Recently, from their research in contemporary workplaces, including lean production sites, Hoyles et al. (2010) suggest the term 'techno-mathematical literacies' to capture the complex embedding of mathematics into technological, particularly computer-based tools in many workplaces. Wedege (2000, 204), in a study of technology-rich 'new' workplaces in Denmark uses the term 'technological competence' to capture what numeracy means and the form it takes in the workplace. This term encapsulates the expressions of mathematical knowledge and skills in the workers' accomplishments, sense making and agency. This would include their labour for the organisation's business and also their status as workers who have rights and aspirations. 
In addition to the workplace-specific studies cited above, most of which were based on ethnographic methodologies, there has been a growing number of studies highly critical of how findings from large scale international adult literacy surveys have been interpreted to generate adult literacy crises. In the UK for example, Hamilton (2001, 2012a) and Hamilton and Barton (2000), key advocates of the social practices approach, indicate that these surveys selectively privilege particular types of literacy and numeracy practices, which are unlikely to represent the myriad local 'situated' uses and meanings of such practices. In particular, Hamilton (2012b) outlines the political processes through which international survey findings become 'translated' into a crisis discourse and henceforth to national policies which reach into the pedagogy of adult literacy classrooms. Other researchers have critiqued the 'levels' of literacy and numeracy in international surveys, indicating their misuse for making international comparisons and promoting particular models of literacy (e.g. St. Clair 2012). Black and Yasukawa (2013) demonstrate that the use of the level 3 criterion in the Australian ALLS findings, i.e. the minimum required for individuals to meet the complex demands of everyday life and work in the emerging knowledge-based economy (Australian Bureau of Statistics 2007, 5), is unjustified due to lack of evidence. And yet, the level 3 criterion, as we indicated earlier in this paper, has been responsible for much of the reporting on the quantification of the literacy 'crisis' by various government and skills organisations (including, for example, the seven millions adults 'that just can’t do it').

\section{Lean production}

Before considering methodology and findings, brief mention needs to be made of lean production because this paper is based on research in three manufacturing companies in various stages of re-organising their production methods to lean production processes. Lean production describes a highly influential form of workplace organisation which derives largely from Japanese production methods (e.g. Monden 1994). Efficiency is the aim, involving the ongoing reduction of resources (people, equipment), surplus production and stock, and unnecessary capital investments. It is often characterised as 'just-in-time' - producing parts in the right quantity and at the right time, using high technology in seamless production stages. It usually involves small teams of multiskilled workers taking increased responsibility for meeting production targets with the aim of continuous improvement, drawing on the knowledge of the teams to provide insights and suggestions for greater efficiencies (e.g. Womack, Jones and Ross 1990; Nicholas 2011). Increasingly peak Australian industry organisations view the application of lean principles to be 'at the heart of modern enterprises' (Manufacturing Skills Australia 2012, 57), which is the main reason we focused on 'lean' companies, and especially in view of industry's perception that they require more 'sophisticated' skills, including literacy and numeracy. Thus researching 'lean' companies was seen to have relevance in the contemporary manufacturing/industrial environment.

\section{Methodology}

Adopting an ethnographic perspective, we describe aspects of the everyday work life of production workers. Street (2012, 39) describes an ethnographic perspective as allowing non-anthropologists to make good use of some of the features of ethnographic methods 'without having to become fully fledged anthropologists'. The ethnographic tools used 
in this study include observations of workplace practices, asking questions though semistructured open-ended interviews, and field notes of production work. In these ways the study seeks to understand local meanings - essentially how workers view their work. It also requires reflexivity on the part of the researchers as they enter the research sites with a set of assumptions based on their own common sense understandings. To disrupt these understandings, Street $(2012,75)$ suggests the need for researchers to 'enter the situation and then retreat to consider before entering again'. The research team engaged in this cyclical process with multiple visits to each of the three research sites. As we indicated in the earlier literature, a focus on workplace practices (as literacy and numeracy practices) involves analysing local events or activities and locating them as part of wider patterns of socio-cultural practices.

The three manufacturing companies for this study were selected following personal recommendations from three sources: a peak industry group, a leading 'lean' training organisation, and a public VET provider. The aim was to locate three mediumsized companies that were: implementing lean production methods and training, willing to cooperate in a research project, and accessible for the researchers for regular visits for observations and interviews. The selected companies were located on the industrial outskirts of capital cities in two Australian states.

The three companies were diverse in a number of ways, including their products and their organisational structures, but similar in the composition of their production workforces - with workers mainly born overseas with English not being their first language, and generally holding no prior formal qualifications related to their current work. We use pseudonyms for the three companies: Hearing Solutions assembles, repairs and distributes hearing aids; Secure Windows assembles and distributes various door and window locks and mechanisms; and Insulation Products manufactures and distributes a range of industrial gaskets and insulation products. All three companies mainly serve the Australian domestic market. While some of their product components are produced overseas (e.g. electrical hearing aid components in Poland, and door locks in China), the custom-made assembly and efficient turnaround of orders, together with lean production processes (at least, in two of the companies), appear to enable these companies to remain competitive in a climate of general decline in Australian manufacturing.

In relation to lean production training, Hearing Solutions has completed the first certificate level training in which every single production worker and several managers participated. This 'whole-of-organisation' approach to training is an example of this company's embrace of lean principles. Secure Windows has partly embraced lean principles with a group of 18 key workers having completed the training programme, with on-going work-based lean production initiatives being developed. Insulation Products is in the very first stage of introducing lean production, with an external training provider delivering introductory training to a group of 12 workers.

The three researchers visited each company on multiple occasions (averaging more than seven visits to each company) for observations of a wide range of production work tasks, including team meetings, and individual interviews with workers, trainers and managers (over 50 interviews were recorded and later transcribed in full). The 
interviews were undertaken in work locations that included the production floor, board rooms, training rooms, lunch rooms, supervisors' offices and other locations available at the time. The main data collection phase extended for approximately eight months.

\section{Embedded literacy and numeracy practices at work}

For the purposes of this paper, we classify the main embedded literacy and numeracy practices according to three domains: firstly, what we term the routine technical work practices of the workers - the main production tasks or activities they engage in; secondly, literacy and numeracy practices specifically related to various aspects of 'lean' production work, the so-called 'more sophisticated skills' flagged by an industry organisation; and thirdly, conditions of employment related to 'earning a living', involving for example, negotiating pay schedules and contracts. As other research studies have shown (e.g. Worthen 2008), conditions of employment can be seen to represent workplace activities separate from those relating to productivity. These three workplace domains are not self contained - there are overlaps, but they are used here in a heuristic way to structure our data and analyses. We note that our study is not an indepth 'audit' of all embedded literacy and numeracy practices in the three companies, rather, selected practices pertaining to key areas of production work identified by the workers.

\section{Technical work practices}

In all three companies, producing or reading and interpreting job cards is the primary routine technical work task involving literacy and numeracy. Generating a job card is usually the first stage in the production process, and the card usually accompanies the development of the product as it moves through the various production stages until final despatch to the customer. Though they all differ in specifications, job cards have generic features - they are usually one-page pro-formas identifying the job with sections detailing dates, customers, addresses, technical data including the specific details of the type of material, dimensions and quantity of the item to be produced, and names/signatures of workers or supervisors. The job card is a key workplace text, a material artefact to be read, checked and signed by the relevant workers and then passed on to the next production stage. Signing off the job card is often the only writing involved.

An individual worker's level of interaction with the job card varies according to the job they perform. For data entry clerks at Hearing Solutions, their primary role is to produce the cards based on client orders (received mainly by emails and phone calls). In most work tasks in all three companies though, the job cards are used in a very routine way, involving simply the checking of a few details in the production process. In some job tasks there is greater engagement with the job card, such as the modellers' work at Hearing Solutions where they produce three dimensional computer models of in-theear, personalised hearing aids. They need to cross-check the job card details and occasionally they are required to email their customer service section for clarification. As one worker indicates: 'We write a little paragraph, as short and concise as possible'. 
Literacy and numeracy practices also feature in data entry and despatch/ warehouse work, such as in calculating transport costs to ensure best value thus ensuring products are despatched efficiently at minimum cost to the company.

Reading instructions in 'manuals' might also be expected to comprise literacy and numeracy practices in a range of activities. However, there was little evidence in the three companies of the need to refer to such manuals. Only in one section of one company did a team leader refer to the need to look up a manual, and it involved using the company's intranet to remain up to date with new products. Beyond this, in the mainly routine work of most job roles, we found little evidence of workers referring to manuals to learn how to perform their job role, or indeed to troubleshoot when problems arose. Instead, workers learnt primarily by observing others and receiving informal help from their fellow team members.

\section{Mathematics/numeracy practices - visible and invisible}

Mathematical or numeracy practices in some cases feature more prominently than literacy practices. This is the case at Insulation Products where precise measuring is required to produce a range of gaskets and other insulating products and to eliminate wastage. One job involves producing insulation blankets that surround large pipes. These are custom-made blankets in which a worker calculates the circumferences of the pipes, taking into account the thickness and flexibility of the material, possible abrasion at key points, and large joints and taps. Stores and despatch workers in this company also spend time measuring and counting material distributed to other work sections and checking final products, readying them for final despatch to customers.

One significant set of work practices where it is difficult to be specific about, in fact quite difficult even to recognise embedded mathematics or numeracy, involves the use of numerically controlled machines and computer-aided design (CAD) software. At Hearing Solutions modellers work exclusively on computer generated threedimensional images of in-the-ear hearing aids using CAD programmes. The images are obtained from scans of the impression or mould of a client's ear canal sent by the audiologist. The modeller, by manipulating a dual mouse system, is required to re-shape the image to produce a model of an optimum-fit hearing aid 'shell', incorporating the specific electrical components required to fit the client's specific hearing needs. This model is then sent to a three dimensional 'printer' that produces the acrylic outer 'shell' of the hearing aid. The modelling work clearly depends on highly complex mathematical algorithms, but these are not visible either to the modellers or to those observing their work practices. The embedding of the calculations in the CAD software renders the underlying mathematical calculations of these actions invisible. 'Invisibility' however, does not equate with 'absence'. In the mathematical education research literature, as we cited earlier, these types of practices can be termed 'technomathematical literacies' (Hoyles et al. 2010).

\section{Implementing lean processes}

To explore literacy and numeracy practices in working within lean processes, we focus mainly on Hearing Solutions where the implementation of lean processes is the most advanced of the three companies. 
Participating in self-directed teams requires workers to engage with a number of distinct practices. Daily team meetings (of 10 minutes duration) are a key element where the team's performance is discussed around the team's 'business board' (a large whiteboard featuring a range of performance details). The previous day's production is analysed, current daily work demands discussed, suggestions are made for further improvements, and any other issues/problems in the team are raised at these meetings.

Literacy (including spoken English) and numeracy are embedded in all aspects of these team-based lean work practices, and especially public speaking in English to the whole team. At Hearing Solutions chairing team meetings is rotated weekly so that every team member undertakes this public speaking role. Further, the daily team meetings encourage, and are an opportunity for, workers to express their views on many aspects of the team's work, and this requires spoken English. One manager stated that the main change he witnessed in the shift to lean production was that previously workers would 'sit down in a meeting and you wouldn't hear a word from anyone'. But the daily team meetings had resulted in workers being 'a bit more involved ... I find they open up a lot more ... sometimes you get brilliant suggestions on how to do things'.

Collating the team's daily productivity outputs in the form of graphs, and reading the graphs to determine the team's productivity at any point in time and whether performance targets are being met, comprise the most obvious numeracy practice. Literacy practices are in evidence in all written documentation in the teams - including the corporate 'vision' statements for each team, the names of team members accompanying their photographs, and details of social events, such as the birthdays of team members. In keeping with lean's visual management system there is also a laminated diagram at each work station indicating the correct placement of all workplace tools. In the everyday work of team members, however, there are very few writing practices, mainly reading graphical texts.

\section{Conditions of employment}

The third domain of workplace literacy and numeracy practices involves conditions of employment - 'earning a living' issues, such as how workers negotiate their working conditions, including pay rates, sick leave, safety and workers' compensation if injured at work. This domain appears to have been neglected in most studies of literacy and numeracy in workplaces, but from the workers' perspectives, their work contract and how they negotiate their working conditions are central to their working life. Clearly, understanding and signing written work contracts, and negotiating working conditions in personal negotiations with managers incorporates literacy and numeracy practices. Working safely is also a major consideration for workers, including reading safety instructions and workplace signage.

\section{Literacy and numeracy problems and issues}

Having identified a range of key workplace practices with embedded literacy and numeracy in the production work in these companies, we now consider the perspectives of various company personnel in relation to how workers manage these practices. We begin with the perspectives of the workers themselves, including team leaders, followed 
by the trainers of workplace programmes, and then we conclude with the perspectives of managers.

\section{Production workers' perspectives}

Workers' perspectives are rarely documented, or indeed sought in relation to workplace literacy and numeracy practices. With regard to technical routine workplace practices, it was clear that workers perceived there rarely to be any 'problems' with literacy and numeracy, regardless of the level of the work task. Reading the job cards properly, for example, was no problem for any of the workers, including those with little formal education in English. This was due in part to daily familiarity with the cards, as a Vietnamese-born worker at Hearing Solutions indicated: 'Yeah, we have to read the form. But not hard for me (to) read the form every day ... So the form is all the same'. And if these workers did come across something on the card they did not understand, working as part of a small team, it was a simple matter of seeking clarification from the team leader or a fellow worker. If mistakes with job cards did occasionally occur, the workers attributed this to a loss of concentration or a temporary distraction, not the inability to read the card.

In the work involving highly technical computerised machine tools - such as the modellers' computer interface at Hearing Solutions, or in programming water or laser cutting machines at Insulation Products, the key issue was not literacy and numeracy ability, rather, the workers' computing knowledge and experience. There can be little doubt that this highly technical work is specialised and literacy and mathematical concepts may well have been present in this work, though often 'invisible' to the workers and us as researchers. The main point, nevertheless, is that no worker claimed that operating these computerised machines successfully was contingent in any way on their literacy and numeracy abilities. Moreover, the workers using these machines tended generally to under-value their skills in undertaking these work roles. One of the modellers at Hearing Solutions, for example, provided a detailed description of the many complex factors he needed to consider in his work, but then described this work as 'just like playing a video game, basically'. Similarly an operator of the computer controlled cutting machines at Insulation Products described the numeracy calculations to determine how many gaskets could optimally be obtained from sheets of material as: 'nothing much actually. Very basic actually, very basic'.

Writing in English might well have been considered a 'problem' by many of these workers, but very little writing was actually required in these work tasks. For most workers in all three companies, the main writing involved signing off the job card, or appending details to the card. The only routine production work tasks that required any writing in prose style was that of the modellers emailing their customer service officers regarding technical queries about particular client orders. The point here is that even if the workers believed their written skills were not particularly good, they were nevertheless quite sufficient to undertake all their current work practices.

Given the extent of the linguistic and cultural diversity in each company, spoken communication in English was potentially a 'problem' in the production work in the three companies, but no workers claimed poor spoken English caused anything more 
than an occasional misunderstanding or irritant, and that there were no perceived production implications. A certain level of pragmatism seemed to prevail among workers on the production floor. For example, in one of the companies where there was an official 'English only' policy, a group of Tamil workers in the same team nevertheless spoke in their native language to each other much of the time. One of these workers commented: 'Mostly we speak Tamil, but if anyone come from outside or other nationality comes, then we need to speak English ...' A few fellow workers expressed the view that they were not always happy at being excluded from conversations in languages they did not understand, but this was not considered a significant 'problem' among workers.

Levels of spoken English might potentially be an issue in some specific lean processes, and especially the daily team meetings where workers were expected to run the meetings and contribute to discussions in English. However, in our observations of several team meetings in two of the companies, and in interviews with the workers, there was no evidence of any significant misunderstandings resulting from the workers' spoken English, though inevitably there were grammatical and pronunciation errors and difficulties with accents. Sometimes it meant team members were required to have a certain level of cross cultural understanding and patience. Grappling with different accents and some poor English pronunciation was seen as an accepted facet of working in a culturally and linguistically diverse workplace. In fact, the team meetings were a positive opportunity for workers to improve their spoken English, which was the case for one Vietnamese-born worker who spoke of chairing a team meeting: 'If I got opportunity (to improve her English) I will take it'. Another worker said he specifically asked not to be placed in a team with fellow Serbian speaking workers so that he could improve his English. For him, therefore, the 'problem' would have been speaking his native language at work, rather than speaking English.

Few workers identified specific literacy and numeracy problems in relation to their working conditions, our third domain of literacy and numeracy practices, though in one company workers were unable to understand the written minutes of a meeting between management and workers over workplace roles. This appeared to be due partly to the formal written style of the minutes (which read in part: 'the status quo leaves a conundrum for purchasing personnel ...').

Many of the workers did have problems with their working conditions (e.g. low pay, few opportunities for advancement, lack of documentation about pay scales at one company). One related problem at Insulation Products was how to improve their pay given the lack of documentation. In such a case it was left to the worker to ask in person, as one indicated: 'Nobody knows whom to ask. So maybe we need to go and ask (the Production Manager) or he will say, okay, leave it to me, leave it to me for eight months, nine months'. The act of asking the Production Manager for a pay rise, requiring a specific spoken English practice, may well present as a 'problem' for workers in the company. Safety compliance in this same factory was also a 'problem' for these workers, but not because they were unable to read safety signs, rather, because there was a general workplace culture in the company which did not focus sufficiently 
on safety, despite one of the buildings being destroyed by fire a few years earlier. One worker claimed nothing would change 'until someone gets hurt'.

\section{Trainer perspectives}

There were external trainers (of the lean production course) in all three companies, and consistent with the views of the workers in the previous section, these workplace trainers failed to identify literacy and/or numeracy 'problems' on the part of the workers. No examples could be provided of workers not performing their job roles effectively, or productivity being affected in a negative way in the companies. Spoken English, in view of the language backgrounds of the workers in all three companies, was a discussion point, but not a problem. As one trainer, indicated, if in a normative sense it was felt workers might experience some difficulties with their level of spoken English, this was more than compensated by their other work skills, and besides, their spoken English was deemed sufficient for the jobs they were doing. For example, the trainer at Hearing Solutions recounted the situation with one of the team leaders:

You'll notice [Minh], he feels not that confident with his English, but some of his graphs on Excel that he has done are amazing. So it's more the spoken English rather than the technical ... In fact, he just went to Poland for a couple of weeks to train them over there ... it's just that English is not their first language.

This trainer considered Hearing Solutions to be a 'fairly sophisticated' company, and the issues affecting productivity were not linked with the literacy and numeracy abilities of workers, but other skills: 'sometimes it's computer illiteracy that's hurting them these days'. Moreover, according to this trainer, the real literacy and numeracy 'problems' in manufacturing companies were seen not to reside within the workers, but in the way documentation was produced and presented to the workers. She provided examples of workplace documentation that was overly complex, and which could be simplified visually, making it easier for everyone in the company to understand.

Similarly, the external trainer at Insulation Products claimed that literacy and numeracy issues in the workplace were related to 'systems' and not a matter of individual workers lacking skills. She stated that most team members did not have to do any paperwork, and therefore with no demand on workers' literacy and numeracy skills, 'you start losing it if you're not using it ... we've dumbed down the workplace'. Part of this workplace trainer's role was to analyse each area of the company's production work to determine the language, literacy and numeracy demands, and whether there was the need for literacy and numeracy support of some kind. Her overall assessment of Insulation Products represents a useful summary of literacy and numeracy issues/problems in relation to production workers at this company:

There's a fair bit of writing up in the warehouse, but they seem to be coping with that ... we talked to management, we talked to the operators ... about problems and where the problems were. There didn't seem to be anything coming up from people misreading or writing incomprehensibly. There's a bit on the verbal communication, but people understand that they have to work a little bit harder at that, so I don't think that was a major one ... So I think 
really, possibly some pronunciation stuff would support people, but people seem to be able to read their job cards. They can read the programmes to put information into, to put the design into the machines. There's really not that much call for it (for literacy and numeracy support).

\section{Employer perspectives}

Managers were interviewed in the three workplaces, including those with responsibilities for production, quality assurance and specialised technology, and significantly, their views did not accord with the dominant industry discourse outlined at the beginning of this report. For example, the specialist technical manager at Hearing Solutions was asked hypothetically by the researchers whether it would make a difference to productivity if the English language, literacy and numeracy skills of all the workers improved. He answered: 'To be honest, no. I would say no. I don't think it would. Not on the productivity level, no'. This manager, highly experienced in hearing aid production work, further explained:

I'd never make language a big or the number one basis of do we employ someone because of that. It was always the skill level. It was always the person's ability to be able to adapt to certain things. Hand skills were the most important that we needed here.

For the Production Manager at Secure Windows, only in one particular production area, the warehouse, did he perceive literacy and numeracy could be an issue. Asked if lack of literacy and numeracy inhibited production in the company, he stated: 'I don't perceive it as a problem, no'. In the main 'assembly' area of the production work he said the workers did not have to do much reading and writing on a day-to-day basis.

The findings from the third company, Insulation Products, were a little mixed. The owner/manager indicated the importance of measurement accuracy in ensuring his company's products (gaskets mainly) were made properly, but when asked directly whether communication and maths were a serious problem in this company, he responded: 'No, it's not serious ... But look, it'd be good to have one less problem ...'

The quality manager in the same company, who worked very closely with production supervisors, was particularly frank about the realities of literacy and numeracy on the production floor. He did not think that speaking other languages (than English) or different accents presented barriers to communication in the production area, and the key factor for him was worker attitude. He summed up factory work as follows:

Factory work is not a sophisticated thing. The operator even - the machines here are sophisticated, but the operator basically put the material into the machine, press the button. Everything is controlled from the top. The only thing that they have to write down in the job card is how - what time do you start, what time do you finish. With your name - that's all, nothing else.

There was little evidence from the managers that lean production work necessarily highlighted literacy and numeracy problems in the workplace. At Hearing Solutions, for example, every single worker had completed the lean production certificate course, 
regardless of their language or educational backgrounds. This was accomplished partly through the support of team leaders and fellow workers, and the on-the-job delivery mode of the course. When asked about the role of literacy and numeracy, the Production Manager claimed they were not an issue: 'I guess we find a way around it. So it didn't stop anyone getting training or learning something ... No, it’s not blocking us’.

Inevitably in companies where English was not the first language in the workforce, there would be occasional misunderstandings to resolve. For example, the manager at Secure Windows said there had been misunderstandings over a workers' compensation issue that was only resolved when a relative of the worker acted as a translator. On another occasion when the company was experiencing a downturn, the message conveyed to workers regarding possible redundancies needed to be translated into seven languages to ensure the information was communicated to all workers. These are largely issues relating to working conditions and not directly productivity-oriented.

Safety was another issue. Accidents resulting from workers not being able to read safety signs are often flagged in the mainstream industry literature as a problem, but it was not a problem in evidence in these companies. The quality manager at Insulation Products, for example, made it clear that in his opinion accidents were not related to reading problems:

I would say it's a problem of attitude rather than literacy ... all the sign(s) are strictly made so you don't have to read a thing ... they put a picture of a forklift, it's something visual ... Nearly everything - all the signs work in that way where you have to read nothing.

\section{Implications and conclusions}

We began this report with accounts of the generally accepted, in fact, common-sense view that low levels of literacy and numeracy among Australian workers are correlated with low productivity with implications for the competitiveness of individual companies and the nation. This is the 'crisis' we investigated in three manufacturing companies. In Australia there have been few published studies that present perspectives contrary to this discourse on literacy and numeracy in workplaces. But the findings presented in this paper do represent such contrary perspectives, based on the voices of workers, trainers and managers in the three manufacturing companies.

Our research findings reflect situated experiences and perspectives on workplace literacy and numeracy practices that by definition cannot be found through large scale survey research or through surveys of the views only of employers. These qualitative findings in the three workplaces offer little to substantiate claims made in policy and industry discourses that there is a literacy and numeracy 'crisis' in the Australian workforce. Workers, trainers and most managers were clear in their comments that improving the literacy and numeracy levels of workers would make little difference to productivity outcomes in these companies - literacy and numeracy were simply not seen to be barriers to how workers performed in their existing jobs. What mattered for all of these stakeholders was how competent workers were in the jobs they performed, which 
appeared to be relatively independent of an individual worker's literacy or numeracy skills.

We are not claiming that there are no benefits to workers from receiving literacy and numeracy support in or outside the workplace. One of the conclusions in the recent Wolf and Evans (2011) study in the UK was that, as with our findings, the productivity benefits of workplace literacy and numeracy programmes were difficult to establish. However, they also found there were individual benefits for some workers in these programmes, such as a changed attitude and interest in additional formal learning, and small gains in measured English language skills for workers for whom English was an additional language. In our study workers in one of the companies viewed a workplace literacy/numeracy program quite favourably, and other workers in the study had voluntarily attended external adult literacy/numeracy classes and were keen to improve their spoken English, literacy and numeracy. Nevertheless, we found little evidence that these efforts would necessarily transfer to improved productivity on the factory floor largely because these workers already demonstrated sufficient skills for the work they were doing. Moreover, depending on the opportunities available to them, workers had demonstrated the capacity to learn and adapt to the introduction of new technologies (e.g. the computer operated 'modelling' or cutting machines) and changing organisational structures (e.g. 'lean’ processes).

While the implications of this study are necessarily limited by its qualitative focus on only three companies, the findings nevertheless challenge the link made between literacy/numeracy and productivity which is the key element, the cornerstone of the workplace literacy and numeracy discourse in Australia. This discourse is currently used to justify the increasingly significant allocation of public resources for particular adult literacy and numeracy programmes and products (National Quality Council 2010). This study highlights a contradiction between the rhetoric of the dominant discourse 'crisis' on workplace literacy and numeracy that informs national policy (as outlined in the Strategy), and the realities of production work as articulated by workers, trainers and managers in three production companies. Thus the situated perspectives of these company personnel provide an alternative perspective to a production workforce seen largely to be 'in deficit' in relation to how they manage literacy and numeracy practices.

The key implication of this paper therefore, is that the dominant discourse on workplace literacy and numeracy in Australia needs to be questioned more closely. There needs to be greater analysis of the processes through which large scale literacy/numeracy survey data in particular, and also the perspectives of employers, become 'translated' into a crisis discourse and national policy (see Hamilton 2012b), while at the local workplace level there can be a complete absence of such a crisis.

\section{Acknowledgements}

Funding and support for this project was provided by the Australian Government Department of Industry, Innovation, Climate Change, Science, Research and Tertiary Education through the National VET Research and Evaluation Programme managed by the National Centre for Vocational Education Research. The views and opinions expressed in this article are those of the authors and do not necessarily reflect the views of the Australian Government or NCVER. 


\section{Notes on contributors}

Stephen Black is a senior researcher at the University of Technology, Sydney. He has taught, coordinated programs and researched in the field of adult literacy and numeracy for many years. His publications have focused mainly on critical studies of adult literacy and numeracy from a social practice perspective.

Keiko Yasukawa is a lecturer in adult education at the University of Technology, Sydney. Her research interests focus on the tensions between policy, practice and pedagogy in adult numeracy and literacy. She is a member of the editorial team for the journal Literacy and Numeracy Studies: An international journal in the education and training of adults.

Tony Brown is a senior lecturer in adult and organisational learning at the University of Technology, Sydney. His research focuses on the history and political economy of work and learning. Tony is also the editor of the Australian Journal of Adult Learning.

\section{References}

Ananiadou, K., A. Jenkins, and A. Wolf. 2004. Basic skills and workplace literacy: What do we actually know about the benefits? Studies in Continuing Education 26, no. 2: 289-308.

Apple, M. 1987. Foreword. In Literacy, schooling and revolution. C. Lankshear and M. Lawler. London: Falmer.

Aronowitz, S., and H. Giroux. 1985. Education under siege: The conservative, liberal, and radical debate over schooling. South Hadley: Bergin \& Garvey.

Australian Broadcasting Corporation. 2010. ABC Radio National interview on 'Workforce futures' with G. Doogue, P. Bullock, and H. Ridout.

$<$ http://www.aigroup.com.au/portal/binary/com.epicentric.contentmanagement.servle t.ContentDeliveryServlet/LIVE_CONTENT/Publications/Speeches/2010/workforce futures transcript_web.pdf>

Australian Bureau of Statistics. 2007. Adult literacy life skills survey, summary results, Australia. Canberra: ABS.

Australian Government. 2010. Budget 2010-11: skills and infrastructure - building a stronger and fairer Australia. Canberra: Australian Government.

Australian Industry Group. 2010. National workforce literacy project: Report on employers' views on workplace literacy and numeracy skills. North Sydney: AIG.

Australian Industry Group. 2012. When words fail: National workforce literacy project, final project report. North Sydney: AIG

Australian Workforce and Productivity Agency. 2013. Human capital and productivity: Literature review. Canberra: AWPA

Barton, D. 2007. Literacy: An introduction to the ecology of written language. Oxford: Blackwell. 
Barton, D., and M. Hamilton. 1998. Local literacies: Reading and writing in one community. London: Sage.

Baynham, M. 1995. Literacy practices: Investigating literacy in social contexts. New York: Longman.

Belfiore, M., T. Defoe, S. Folinsbee, J. Hunter, and N. Jackson. 2004. Reading work: Literacies in the new workplace. Mahwah: Lawrence Erlbaum Associates.

Black, S. 2004. Whose economic wellbeing? A challenge to dominant discourses on the relationship between literacy/numeracy skills and (un)employment. Literacy and Numeracy Studies 13, no. 1: 7-18.

Black, S., and K. Yasukawa. 2011. A tale of two councils: Alternative discourses on the literacy 'crisis' in Australian workplaces. International Journal of Training Research 9, no. 3: 218-33.

Black, S., and K. Yasukawa. 2013. Level 3: Another single measure of adult literacy and numeracy. The Australian Educational Researcher. DOI 10.1007/s13384-0130097-9.

Canberra Institute of Technology. 2010. Literacy and numeracy are holding Australia back. Industry Connection. $<\underline{\text { http://cit.edu.au/partnerships/industry_connection/2010_june/literacy_and_numerac }}$ y_holding_australia_back>

Darrah, C. 1996. Learning and work: An exploration in industrial ethnography. New York: Garland.

Department of Employment, Education and Training. 1991, Australia's language and literacy policy. Canberra: Australian Government Publishing Service.

Derrick, J. 2012. Embedding literacy and essential skills in workplace learning: Breaking the solitudes. Montreal: The Centre for Literacy.

Fairclough, N. 1989. Language and power. New York: Longman.

Farrell, L. 2006. Making knowledge common: Literacy and knowledge at work. New York: Peter Lang.

Fenwick, T. 2010. Policies for the knowledge economy: Knowledge discourses at play. In The Sage handbook of workplace learning, eds. M. Malloch, L. Cairns, K. Evans, and B. O'Connor. Thousand Oaks: Sage.

Foley, G. 1999. Learning in social action: A contribution to understanding informal education. London: Zed Books.

Freebody, P. 1997. Assessment as communal versus punitive practice: Six new literacy crises for Australia. Literacy and Numeracy Studies 7, no. 2: 5-17.

Freebody, P., and A. Welch. (1993) Individualisation and domestication in current literacy debates in Australia. In Knowledge, control and power: International perspectives on literacy as policy and practice, eds. P. Freebody and A. Welch. London: Falmer.

Gallo, M. 2004. Reading the world of work: A learner-centred approach to workplace literacy and ESL. Malabar: Krieger.

Gee, J. 1990. Social linguistics and literacies: Ideology in discourses. London: Falmer..

Gee, J., G. Hull, and C. Lankshear. 1996. The new work order: Behind the language of the new capitalism. Sydney: Allen \& Unwin. 
Gowen, S 1992, The politics of workplace literacy: A case study, Teachers College Press, New York.

Gowen, S. 1996. How the reorganisation of work destroys everyday knowledge. In Alpha 96: Basic education at work, ed. J. Hautecoeur. Toronto: Culture Concepts.

Hamilton, M. 2001. Privileged literacies: Policy, institutional process and the life of IALS. Language and Education 15, no. 2: 178-196.

Hamilton, M. 2012a. The effects of the literacy policy environment on local sites of learning. Language and Education 26, no. 2: 169-182.

Hamilton, M. 2012b. Literacy and the politics of representation. London: Routledge.

Hamilton, M., and D. Barton. 2000. The International adult literacy survey: What does it really mean? International Review of Education 46, no. 5: 377-389.

Hart-Landsberg, S., and S. Reder. 1995. Teamwork and literacy: Teaching and learning at Hardy Industries. Reading Research Quarterly. 30, no. 4: 1016-1052.

Hastwell, K., P. Strauss, and C. Kell. 2013. 'But pasta is pasta, it is all the same': The language, literacy and numeracy challenges of supermarket work. Journal of Education and Work 26, no. 1: 77-98.

Hoddinott, S. 1997. The abuses of literacy: The making of a worker 'basic skills' crisis in England and North America. PhD thesis, University of Warwick.

Holland, C., F. Frank, and T. Cooke. 1998. Literacy and the new work order: An international literature review. Leicester: National Institute of Adult Continuing Education.

Hoyles, C., R. Noss, P. Kent, and A. Bakker. 2010. Improving mathematics at work: The need for techno-mathematical literacies. London: Routledge.

Hull, G. 1993. Hearing other voices: A critical assessment of popular views on literacy and work. Harvard Educational Review 63, no. 1: 20-49.

Hull, G. 1997. Changing work, changing workers: Critical perspectives on language, literacy and skills. New York: State University of New York.

Hull, G., M. Jury, and J. Zacher. 2007. Possible selves: Literacy, identity, and development in work, school, and community. In Towards defining and improving quality in adult basic education, ed. A. Belzer. Mahwah: Lawrence Erlbaum Associates.

Hunter, J. 2012. Language and literacy on the ground: Disconnects between government policy and employer perspectives. Discourse: Studies in the Cultural Politics of Education 33, no. 2: 299-311.

Industry Skills Councils. 2011. No more excuses: an industry response to the language, literacy and numeracy challenge. Canberra: Australian Government.

Jackson, N. 2000. Writing-up people at work: Investigations of workplace literacy. Literacy and Numeracy Studies 10, no. 1: 5-22.

Jackson, N., and B. Slade. 2008. 'Hell on my face': The production of workplace illiteracy. In People at work: Life, power, and social inclusion in the new economy, ed. M. DeVault. New York: New York University.

Kell, C., S. Guy, K. Hastwell, and S. Harvey. 2009. Upskilling partnersahip programme: In-house literacy, language and numeracy initiatives in New Zealand workplaces. Wellington: Department of Labour. 
Livingstone, D., and P. Sawchuk. 2005. Hidden knowledge: Working-class capacity in the 'knowledge-based economy'. Studies in the Education of Adults 37, no. 2: 110122.

Manufacturing Skills Australia. 2012. Environmental scan 2012. North Sydney: MSA.

Meadows, P., and H. Metcalf. 2008. Does literacy and numeracy training for adults increase employment and employability? Evidence from the Skills for Life programme in England. Industrial Relations Journal 39, no. 5: 254-369.

Monden, Y. 1994. Toyota production system. London: Chapman \& Hall.

National Quality Council. 2010. Foundation skills in vet products for the $21^{\text {st }}$ century. Melbourne: National Quality Council.

Nicholas, J. 2011. Lean production for competitive advantage: A comprehensive guide to lean methodologies and manufacturing practices. New York: Productivity Press.

Rose, M. 2004. The mind at work: Valuing the intelligence of the American worker. New York: Penguin.

Scheeres, H. 2007. Talk and texts: Beyond language and literacy skills. Literacy and Numeracy Studies 15, no. 2: 5-18.

Shomos, A. 2010. Links between literacy and numeracy skills and labour market outcomes. Canberra: Productivity Commission.

Shor, I. 1986. Culture wars. Boston: Routledge \& Kegan Paul.

Skills Australia. 2010. Australian workforce futures: A national workforce development strategy. Canberra: Commonwealth of Australia.

Skills Australia. 2011. Skills for prosperity: A roadmap for vocational education and training. Canberra: Commonwealth of Australia.

Skovsmose, O., and K. Yasukawa. 2009. Formatting power of 'mathematics in a package. In Critical issues in mathematics education. eds. P. Ernest, B Greer, and B. Sriraman. Charlotte: Information Age Press.

St. Clair, R. 2012. The limits of levels: Understanding the International Adult Literacy Surveys (IALS). International Review of Education 58, no. 6: 759-776.

Standing Council on Tertiary Education, Skills \& Employment. 2012. National foundation skills strategy for adults. Canberra: SCOTESE.

Street, B. 1995. Social literacies: Critical approaches to literacy development, ethnography and education. London: Longman.

Street, B. 2012. New literacy studies. In Language, ethnography and education: Bridging new literacy studies and Bourdieu. eds. M. Grenfell, D. Bloome, C. Hardy, K. Pohl, J. Rowsell, and B. Street. London: Routledge.

Tannock, S. 1997. Positioning the worker: Discursive practices in a workplace literacy program. Discourse and Society 8, no. 1: 85-116.

Wedege, T. 2000. Technology, competences and mathematics. In Perspectives on adults learning mathematics: Research and practice. eds. D. Coben, J. O’Donoghue, and G.E. FitzSimons. Dordrecht: Kluwer Academic.

Williams, J., and G. Wake. 2007. Black boxes in workplace mathematics. Educational Studies in Mathematics 64, no. 3: 317-343. 
Wolf, A., L. Aspin, E. Waite, and K. Ananiadou. 2010. The rise and fall of workplace basic skills programmes: Lessons for policy and practice. Oxford Review of Education 36, no. 4: 385-405.

Wolf, A., and K. Evans. 2011. Improving skills at work. London: Routledge.

Womack, J.P., D.T. Jones, and D. Ross. 1990. The machine that changed the world. New York: Rawson Associates.

Worthen, H. 2008. Using activity theory to understand how people learn to negotiate the conditions of their work. Mind, Culture, and Activity 15, no. 4: 322-338.

Zevenbergen, R., and K. Zevenbergen. 2009. The numeracies of boatbuilding: New numeracies shaped by workplace technologies. International Journal of Science and Mathematics Education 7, 183-206. 